International Journal of Science and Education, 4(2), 111-126

Uluslararası Bilim ve Eğitim Dergisi, 4(2), 111-126

DOI: 10.47477/ubed.975353

Makale Türü: Araştırma Makalesi

Başvuru Tarihi: 28.07.2021

Yayına Kabul Tarihi: 28.08.2021

\title{
Gerçekçi Matematik Eğitiminin Ondalık Gösterimler Öğretiminde 5. Sınıf Öğrencilerinin Başarısına Etkisi*
}

\author{
Kübra KARATAŞ1 ${ }^{* *}$, Nuri Can AKSOY², Devrim ÇAKMAK ${ }^{3}$
}

\begin{abstract}
Öz
$\mathrm{Bu}$ araştırmanın amacı, gerçekçi matematik eğitimi yaklaşımının ortaokul 5.sınıf ondalık gösterimler konusundaki akademik başarı üzerine etkisinin incelenmesidir. Araştırmada karma yöntem ve kolay ulaşılabilir durum örnekleme yöntemi kullanılmıştır. Araştırma grubunu Gaziantep ilinde bir devlet ortaokulunun 5. sınıf düzeyinde 56 öğrenci oluşturmaktadır. Veri toplama aracı olarak Ondalık Gösterim Başarı Testi ve Görüşme Formu kullanılmıştır. Uygulamalar 20 ders saati sürmüştür. Uygulama öncesinde ön test, sonrasında son test ve kalıcılık testi olarak Ondalık Gösterim Başarı Testi uygulanmıştır. Araştırma sonucunda deney ve kontrol gruplarının ondalık gösterimlere ilişkin ön test başarı düzeylerinin istatistiksel olarak anlamlı farklılık göstermemiştir. Son test sonuçlarında ise deney grubundaki öğrencilerin başarı durumlarının, kontrol grubuna göre anlamlı düzeyde daha fazla arttı̆̆ı saptanmıştır. Kalıcılık testi sonuçlarında iki grubun başarı düzeyleri arasında istatiksel olarak anlamlı farklılık bulunamamıştır.
\end{abstract}

Anahtar Kelimeler; Gerçekçi matematik eğitimi, ondalık gösterimler, ortaokul, başarı.

\section{The Effect of Realistic Mathematics Education on the Success of 5th Grade Students in Decimal Notation}

\begin{abstract}
The aim of this research is to examine the effect of realistic mathematics education approach on academic achievement in secondary school 5th grade decimal notations. Mixed method and easily accessible case sampling method were used in the research. The research group consists of 56 students at the 5th grade level of a public secondary school in Gaziantep. Decimal Notation Achievement Test and Interview Form were used as data collection tools. The research lasted for 20 lesson hours. Decimal Notation Achievement Test was applied as a pre-test, post-test and retention test. As a result of the research, the pre-test success levels of the experimental and control groups regarding decimal notations did not differ statistically significantly, and In the post-test results, it was determined that the success of the students in the experimental group, increased significantly more than the control group. There was no statistically significant difference between the success levels of the two groups in the results of the retention test.
\end{abstract}

Keywords: Realistic math education; decimal notation; middle school, success.

\footnotetext{
* Bu çalışma birinci yazarın “Ondalık Gösterimler Konusunun Ortaokul 5. Sınıf Öğrencilerinde Gerçekçi Matematik Eğitimiyle Öğretiminin Başarıya Etkisi” adlı yüksek lisans tezinden üretilmiştir.

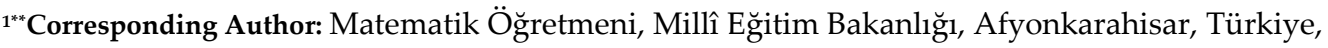
kubraakpinar0712@gmail.com, ORCID: 0000-0001-5718-2544

2 Dr. Öğr. Üyesi, Hasan Kalyoncu Üniversitesi, Gaziantep, Türkiye, ncan.aksoy@hku.edu.tr, ORCID: 0000-00016087-8884

3Prof. Dr., Gazi Üniversitesi, Ankara, Türkiye, dcakmak@gazi.edu.tr, ORCID: 0000-0003-2891-4931
} 


\section{Giriş}

Matematiğin, günlük yaşamda önemli bir yeri olmasına rağmen dünyanın her yerinde öğretilmesi ve öğrenilmesi zor olarak kabul edilmesi matematiğe karşı geliştirilen önyargı, korku ve kaygının doğasından kaynaklanmaktadır (Şahin, 2004, s. 17). Matematik dersi çoğu öğrenci tarafından zor bir ders olarak görülmektedir. Bu nedenle öğrencilerin uzaklaştığı, korktuğu bir ders haline gelmektedir (Dursun \& Dede, 2004). Matematiğin zor olarak düşünülmesi ve matematikten korkulmasının sebeplerinden biri de matematikle ilgili kavramların doğası gereği soyut nitelikte olmasıdır. 7-12 yaş somut işlemler döneminde bulunan derslerdeki soyut kavramların, somut materyallerle desteklenerek işlenmesi özellikle bu öğretim düzeyinde büyük önem taşımaktadır (Erden \& Akman, 2002). Bir diğeri, öğrencilerin matematikte öğrendiklerini gerçek yaşamla ilişkilendirememeleridir. Öğrencilere verilecek gerçek hayat ve matematik konuları arasındaki ilişki matematiği daha anlamlı hale getirecektir.

İlköğretim kademesinde öğrenim gören öğrencilerin matematik gibi soyut bir derste istenen hedeflere ulaşabilmeleri için, konuyu çeşitli araç ve gereçlerle somutlaştırarak ve gerçek hayatla bağlantı kurarak öğrenmeleri gerekmektedir (Bıldırcın, 2012). Bu somutlaştırma bireylerin kendi yaşamı ve çevresiyle ilgili örneklerle yapılabilir (Akkaya, 2010). Matematik dersinin daha somut hale getirilmesinde matematik üzerinde etkisi bulunan bazı kuramlar bulunmaktadır. Bu kuramların başında kuramsal gelişimi eskilere dayanan, yapılandırmacı yaklaşım gibi hem kuramsal olarak hem de uygulama açısından güncel denebilecek Gerçekçi Matematik Eğitimi (GME) kuramı dikkat çekmektedir (Altun, 2006).

Matematiğin bireye aktarılacak bir yapı olarak görülmesini reddederek, geleneksel yaklaşımın birçok düşüncesine karşı çıkan bu yaklaşımın diğer yaklaşımlardan en önemli farklılığı ise başlangıç noktasıdır. GME'ye soyut formüller, semboller, kurallar ve tanımlardan başlamak yerine somut durumlarda uygulamayı öğrenmek amaçlanır. GME'de matematik, organize tümdengelimli bir sistemdir ve öğrenme süreci de bu şekilde düzenlenmektedir (Aydın Ünal \& İpek, 2009, s. 63).

GME, Hollandalı bir matematikçi olan Freudenthal'in kuruculuğunu yaptığı Freudenthal Enstitüsü tarafından matematik eğitimi için geliştirilmiştir. Freudenthal'a göre matematiğin başlangıcı bireylerin gerçek yaşamda karşılaştıkları problemlerle başlar. Ancak sonrasında gerçek yaşam matematikselleştirilerek formal sisteme geçiş yapılmıştır (Altun, 2006, s. 230). GME, gerçek yaşamda bireylerin karşılaştıkları sorunlardan anlam çıkartarak, kendilerine has matematiksel bilgilerin yapılandırılmasını sağlama amacıyla ortaya çıkmıştır. Yaratıcı düşünme becerilerini artırmada etkili olduğu Ismunandar vd. (2020) belirlenen GME'de öğrenme bir problem çözme süreci olarak yorumlanabilmektedir. Aynı zamanda yaratıcı bir insan etkinliği olan matematiğin, problem çözmek için etkili yolların geliştirilmesi ile öğrenileceği savunulur, matematiksel gelişim için ön koşul ise matematiksel gerçekliğin ön plana çıkartılmasıdır (Olkun \& Toluk, 2003, s. 20).

Literatür incelendiğinde GME ile ilgili sayılar ve işlemler, geometri ve ölçme, cebir öğrenme alanlarına yönelik araştırmalara rastlanmıştır. GME yaklaşımı ile sayılar ve işlemler öğrenme alanında yer alan sayılar, aritmetik, işlemler, kesirler, kümeler (Aydın Ünal, 2008; Demirdöğen, 2007; Hirza vd., 2014; Marija vd., 2000; Nama Aydın, 2014; Keijzer, 2003; Uygur, 2012; Özdemir, 2015; Özkaya, 2016), cebir öğrenme alanında (Erdoğan, 2018; Van der Kooij, 2001), geometri ve ölçme öğrenme alanında katı cisimlerin yüzey alanları ve hacimleri, geometri, dönüşüm geometrisi, alan ölçme (Demir,2017; Fauzan, 2002; Korkmaz, 2017; Yuberta vd., 2011) konularında öğrencilerin akademik başarılarına pozitif katkısının olduğuna dair araştırma sonuçları mevcuttur. 


\section{Araştırmanın Önemi}

Yapılan çalışmalar incelendiğinde, GME ile öğretim üzerine farklı çalışmalar yapılmış olmasına rağmen beşinci sınıf düzeyinde ondalık gösterimler konusu üzerine yapılan bir araştırmaya rastlanılmamıştır. Matematik dersindeki pek çok konu gibi kesirler içinde anlatılan ondalık gösterim konusunda da öğrenciler zorlanmakta ve kavram yanılgılarına düşmektedirler. 0,75'in 3/4 ile aynı olduğunun söylenmesi çocuklar açısından kafa karıştırıcı olabilmektedir. Kesir ile ondalık gösterimin öğretiminde temel amaç bu sayıların aynı kavramı ifade ettiğinin anlaşılmasını sağlamaktır (Aykaç, 2008). Ayrıca öğrencilerin ondalık gösterimlerin yazılış ve okunuşlarında başarılı olmaları, dört işlemle yapılan hesaplamalarda kolaylık sağlamakla birlikte, ondalık gösterimler sayı hissi, ölçme, orantısal düşünme ve reel sayı sistemi ile ilişkilidir (Van de Walle vd., 2014, s. 328). Günlük hayatta çoğu zaman kesirlerden ziyade ondalık gösterimlerle karşılaşılır ve hesap makinelerinde işlem yaparken kesirler yerine ondalık gösterimler kullanılır. Ondalık gösterimler ile ilgili edinilen bilgi, beceri ve yapılan uygulamalar sonraki öğrenmelere ve günlük hayattaki uygulamalara yansıyacağından, konuyla ilgili edinilen eksik ve yanlış bilgiler süreklilik kazanarak bireylerin tüm yaşamlarına yansıyacaktır (Palabıyık, 2016). Bu anlamda bu araştırmanın matematik eğitimi alanyazına katkı sağlayacağı düşünülmektedir.

\section{Araştırmanın Amacı ve Araştırma Soruları}

$\mathrm{Bu}$ araştırma ile gerçekçi matematik eğitimi yaklaşımının ondalık gösterimler konusundaki öğrencilerin akademik başarı üzerine etkisinin incelenmesi amaçlanmıştır. Ortaokul 5.sınıftaki ondalık gösterimler konusunun GME yaklaşımıla işlendiği deney grubu öğrencileri ve mevcut öğretim yöntemiyle işlendiği kontrol grubu öğrencilerinin akademik başarı düzeylerinin anlamlı bir farklılık gösterip göstermediği belirlenmeye çalışılmıştır. Bu amaçla aşağıdaki sorulara cevap aranacaktır.

1. Gerçekçi matematik eğitimiyle derslerin işlendiği deney grubu öğrencileri ile mevcut öğretim yöntemiyle derslerin işlendiği kontrol grubu öğrencilerinin ön test başarı puanları anlamlı farklılık göstermekte midir?

2. Mevcut öğretim yöntemiyle derslerin işlendiği kontrol grubundaki öğrencilerin ön test başarı puanları ile son test başarı puanları anlamlı farklılık göstermekte midir?

3. Gerçekçi matematik eğitimiyle derslerin işlendiği deney grubundaki öğrencilerin ön test başarı puanları son test başarı puanları anlamlı farklılık göstermekte midir?

4. Gerçekçi matematik eğitimiyle derslerin işlendiği deney grubu öğrencileri ile mevcut öğretim yöntemiyle derslerin işlendiği kontrol grubu öğrencilerinin son test başarı puanları anlamlı farklılık göstermekte midir?

5. Gerçekçi matematik eğitimiyle derslerin işlendiği deney grubu öğrencileri ile mevcut öğretim yöntemiyle derslerin işlendiği kontrol grubu öğrencilerinin kalıcılık testi başarı puanları anlamlı farklılık göstermekte midir?

6. Mevcut öğretim yöntemiyle derslerin işlendiği kontrol grubundaki öğrencilerin son test başarı puanları ile kalıcılık başarı puanları anlamlı farklılık göstermekte midir?

7. Gerçekçi matematik eğitimi ile derslerin işlendiği deney grubundaki öğrencilerin son test başarı puanları kalıcılık testi başarı puanları anlamlı farklılık göstermekte midir?

8. Gerçekçi matematik eğitimi ile derslerin işlendiği deney grubundaki öğrencilerin sürece yönelik görüşleri nelerdir?

\section{Yöntem}

\section{Araştırmanın Modeli}

Araştırmada karma yöntem kullanılmıştır. Bu yöntem, bir çalışmada nitel ve nicel araştırma verilerinin birleştirilerek kullanılmasını kapsamaktadır (Creswell, 2013). Karma yöntemlerden açıklayıcı ardışık desenden yararlanılmıştır. Nicel bulguları nitel verilerle desteklemek amacıyla deney grubu öğrencileriyle yapılandırılmış görüşmeler gerçekleştirilmiştir. Araştırmada öncelikle nicel veriler 
toplanmış ve analiz edilmiştir. Devamında nicel sonuçlara bağlı kalınarak nitel araştırma yapılır. Son olarak nitel ve nicel sonuçlar birbirlerini destekleyecek şekilde analiz edilerek çıkarımlarda bulunulur (Creswell, 2017). Araştırmanın nicel boyutunda ön test son test kontrol gruplu yarı deneysel desen modeli kullanılmıştır. Bu desende, deneysel işlem yalnızca deney grubuna uygulanır ancak ön test ve son test her iki gruba da uygulanır (Creswell, 2016). Deneysel desenin amacl, tahmin edilen sebep sonuç ilişkisini yeniden değerlendirmekle birlikte mevcut durumu kontrollü olarak değiştirmektir (Karasar, 2018). Araştırmanın nitel boyutunda ise görüşme tekniğinden yararlanılmıştır. Görüşme tekniği de insanların bir konu hakkındaki düşüncelerinin tespitine imkân sunmaktadır.

Çalışma grubunu Gaziantep ili bir devlet ortaokulunun 5. sınıf düzeyindeki bir sınıfı kontrol grubunu, bir diğer sınıfı da deney grubunu oluşturmaktadır. Araştırmada kolay ulaşılabilir durum örnekleme yöntemi kullanılmıştır ve çalışmanın yapıldığı okul araştırmacının görev yaptığı okul olması sebebi ile seçilmiştir. Uygulanacak yöntemin araştırmacı tarafından tanınması ve uygulamayı kendisinin yapmasının olabilecek zaman kaybını önleyebileceği düşünülmüştür.

Deney ve kontrol gruplarının belirlenmesinde uygulama yapılan ortaokulun 6 şubeden oluşan tüm 5. sınıflarına araştırmacı tarafından geliştirilen Ondalık Gösterim Başarı Testi ön test olarak uygulanmış testlerden alınan sonuçlara göre, ön test başarı puan ortalamaları arasında anlamlı fark olmayan iki sınıf seçilmiştir. Seçilen sınıflardan biri yansız atama ile kontrol grubu, diğeri ise deney grubu olarak belirlenmiştir. Her iki grupta 28 öğrenciden oluşmak üzere toplam 56 öğrenci üzerinde uygulama yapılmıştır. Araştırmanın nitel boyutunda görüşmeler, yapılandırılmış görüşme formları aracılığıyla yazılı olarak alınmıştır.

\section{Veri Toplama Araçları}

Araştırmada kullanılan veri toplama araçları araştırmacı tarafından hazırlanmıştır. Ölçülen akademik başarı Ondalık Gösterimler Başarı Testi ile, GME yaklaşımı hakkındaki düşünceler ise Görüşme Formu ile yazılı olarak toplanmıştır. Hazırlanan Ondalık Gösterimler Başarı Testi gruplara ön test, son test ve kalıcılık testi olarak kullanılmıştır. Veri toplama araçlarına ilişkin bilgiler aşağıda sunulmuştur.

\section{Başarı Testi}

Araştırmanın nicel boyutunda, araştırmacı tarafından ön test, son test ve kalıcılık testi olarak kullanılmak üzere Ondalık Gösterimler Başarı Testi hazırlanmıştır. Başarı testi hazırlama sürecinde konuya ilişkin 6 kazanıma ait belirtke tablosu oluşturulmuştur. Başarı Testi işlenecek konu ile ilgili olarak farklı kaynaklardan (ders kitapları, soru bankaları vb.) faydalanılarak 6 kazanımın her birinden 10 soru olacak şekilde toplam 60 çoktan seçmeli sorudan oluşturulmuştur. Oluşturulan başarı testi, uzman öğretim üyeleri ile matematik öğretmenlerinin görüşleri alınarak soru kökleri ve şıklar tekrar düzenlenmiştir. Son hali verilen ve 60 sorudan oluşturulan testin pilot uygulaması aynı okulda öğrenim gören 6. sınıf 120 öğrenciye uygulanmıştır.

Pilot uygulama sonucunda madde güçlüğü, madde ayırt ediciliği ve iç tutarlılık dikkate alınarak 20 soruluk nihai teste ulaşılmıştır. Nihai testin KR güvenirlik katsayısı .80 olarak hesaplanmıştır.

\section{Görüşme Formu}

Görüşmede, deney grubu öğrencilerinin uygulama süreci hakkında fikirlerini beyan etmesi amaçlanmıştır. Öğrencilerin süreçte yaşadıklarını ve hissettiklerine yönelik toplamda 6 soru içeren form hazırlanmıştır. Öncelikle matematik eğitimi alanında çalışan iki öğretim üyesi ve iki bilim uzmanından uzman görüşü alınmış ve uzman görüşü doğrultusunda anlatım bozuklukları giderilmiş, öğrencilerin seviyesine uygun olacak şekilde ifade değişikliklerine gidilmiştir. Pilot çalışma benzer deneyimi yaşamış grubunu araştırmanın yapıldığı okulda öğleden sonra eğitim alan bir sınıftan, normal gelişim 
gösteren rastgele seçilmiş 3 öğrenci oluşturmuştur. Pilot çalı̧̧ma sürecinde ise bir gün boyunca araştırmacı tarafından geliştirilen ve bu araştırmada kullanılan gerçekçi matematik etkinlikleri öğrencilerle uygulanmıştır. Pilot uygulama sonrasında görüşme soruları öğrencilere yöneltilmiş ve çocukların cevaplayabilme durumuna göre revize edilmiştir.

\section{Verilerin Toplanması}

Bu çalışma, her birinde 28 'er öğrenci bulunan deney ve kontrol grubunda toplam 56 öğrenci ile haftada 5 ders saati olmak üzere 4 hafta boyunca gerçekleştirilmiştir. Her iki grupta da öğretim süreci araştırmacı tarafından yürütülmüştür. Başarı testi deney ve kontrol gruplarına uygulama öncesi ön test, uygulama sonrası son test ve uygulama bittikten 8 hafta sonra da öğrencilerin " ondalık gösterimler" konusuna yönelik bilgi kalıcılıklarını ölçmek amacıyla kalıcılık testi olarak tekrar uygulanmıştır.

Araştırmacı tarafından hazırlanan ve uzman görüşleri doğrultusunda düzenlenerek oluşturulan görüşme formu, araştırma bitiminde deney grubundaki 28 öğrencinin GME hakkındaki görüşlerini incelemek amacıyla yazılı olarak bir ders saati içerisinde toplanmıştır.

\section{Kontrol Grubu Uygulama Süreci}

"Ondalık Gösterim" konusu mevcut öğretim yöntemiyle, Milli Eğitim Bakanlığı ders kitabı temel alınarak 4 hafta süre ile 20 ders saati işlenmiştir. Süreç tamamlandığında Ondalık Gösterim Başarı Testi son test olarak uygulanmıştır.

\section{Deney Grubu Uygulama Süreci}

Uygulama başlangıcında öğrenciler GME hakkında bilgilendirilerek “Ondalık Gösterim" konusu GME yöntemiyle 4 hafta süre ile 20 ders saati işlenmiştir. Deney grubunda uygulanacak etkinlikler ile ders planları araştırmacı tarafından farklı kaynaklardan, literatürden ve uzman görüşlerinden yararlanılarak oluşturulmuştur. Hazırlanan 8 ders planı içerisinde kazanımlara farklı sayılarda dağıtılmış toplam 19 etkinlik bulunmaktadır. Etkinlikler GME yaklaşımına uygun öğrencilerin gerçek hayatlarında karşılaşabilecekleri durumlardan oluşturulmuştur.

Konu anlatımı 4. haftanın sonunda tamamlanarak Ondalık Gösterim Başarı Testi son test olarak uygulanmıştır. GME ile işlenen dersler hakkında öğrenci görüşlerini almak amacıyla araştırmanın 5.haftasında bir ders saati içerisinde Görüşme Formu deney grubu öğrencilerine dağıtılarak, öğrenci görüşleri yazılı olarak toplanmıştır.

\section{Veri Analizi}

Araştırmada elde edilen veriler bilgisayar ortamında SPSS programı kullanılarak analiz edilmiştir. İstatistik çözümlemelerde, .05 anlamlılık düzeyi temel alınmıştır. Testin her bir maddesi için doğru cevaplara 1, yanlış cevaplara 0 puan kodlanarak toplam 20 puan üzerinden değerlendirme yapılmıştır. Gruplara ait test puanlarının normalliği incelenerek aşağıda belirtilen istatistiki yöntemler aracılığıyla puan ortalamaları arasında anlamlı fark olup olmadığı incelenmiştir.

- Tanımlayıcı istatistikler (Ortalama, Standart Sapma, Frekans),

- Deney ve kontrol gruplarının ön test başarı düzeyleri arasındaki farkın belirlenmesinde İlişkisiz Örneklemler t Testi,

- Deney ve kontrol guruplarının ön test başarı ve son test başarı düzeyleri arasındaki değişimin belirlenmesinde sırasıyla İlişkili Örneklemler t Testi ve Wilcoxon İşaretli Stralar Testi,

- Deney ve kontrol gruplarının son test başarı düzeyleri arasındaki farklılıkların belirlenmesinde Mann Whitney U Testi,

- Deney ve kontrol guruplarının son test başarı ve kalıcılık testi başarı düzeyleri arasındaki değişimin belirlenmesinde Wilcoxon İşaretli Stralar Testi, 
- Deney ve kontrol gruplarının kalıcılık testi başarı düzeyleri arasındaki farklılıkların belirlenmesinde, Mann Whitney U Testi kullanılmıştır.

Öğrencilerin gerçekçi matematik eğitimi hakkındaki görüşleri, içerik analizi ile incelenmiştir. 28 öğrencinin görüşme formu cevapları, çözümlendikten sonra ifadeleri bütün halinde görebilmek amaciyla excel tablosuna aktarılmıştır. Oluşturulan excel tablosunda, yanıtlar bütün olarak incelenerek temalar ve alt temalar oluşturulmuştur.

Araştırmanın güvenirlik hesaplaması için Miles ve Huberman'a (1994) ait olan güvenirlik formülü kullanılmıştır (Güvenirlik Formülü: Görüş Birliğì/Görüş Birliği+ Görüş Ayrılığı). Güvenirlik formülü ile iki uzmanın görüşleri arasındaki uyum oranı belirlenmiştir. Oluşturulan alt tema kodlamalarına göre eş araştırmacının da oluşturduğu alt tema kodlamaları dikkate alınarak yapılan hesaplamalar sonucunda araştırmanın güvenirliği ortalama \%75 çıkmıştır. Bu değer, \%70'in üstünde çıktığı için bu uygulamada yapılan kodlamanın güvenilir olduğu sonucuna varılmıştır (Akay ve Ültanır, 2010).

\section{Bulgular}

Bulgular araştırma alt problemleri sırasıyla sunulmuştur.

\section{Deney ve Kontrol Grubu Öğrencilerinin Ön Test Puanlarının Karşılaştırılması}

Uygulama başlangıcında deney grubu ve kontrol grubu öğrencilerinin ön test başarı puanları normallik ve varyansların eşitliği şartını sağlandığından, ön test puan ortalamalarının karşılaştırılması İlişkisiz Örneklemler t Testi ile sağlanmıştır.

Tablo 1. Deney ve Kontrol Gruplarının Ön Test Puanlarının İlişkisiz Örneklemler $t$ Testi ile Karşılaştırılması.

\begin{tabular}{lllllll}
\hline Gruplar & $\boldsymbol{N}$ & $\boldsymbol{X}$ & $\boldsymbol{S}$ & $\boldsymbol{s d}$ & $\boldsymbol{t}$ & $\boldsymbol{p}$ \\
\hline Deney & 28 & 11,89 & 3,77 & 54 & 0,291 & $0,772^{*}$ \\
\hline Kontrol & 28 & 12,17 & 3,56 & & & \\
\hline
\end{tabular}

Deney ve kontrol gruplarının ön test başarı ortalamaları arasındaki farkın p değeri .05 den büyük olarak hesaplanmıştır ( $p=0.772)$. Analiz sonuçları deney ve kontrol grubundaki öğrencilerin ön test başarı puan ortalamaları arasında farkın anlamlı olmadığını göstermektedir [ $t(54)=0.291, p>.05]$. Bu sonuçlara dayanarak uygulamanın başlangıcında deney ve kontrol grubundaki öğrencilerin ondalık sayılar konusunda başarı durumlarının birbirine denk olduğu söylenebilir.

\section{Kontrol Grubu Öğrencilerinin Ön Test ile Son Test Puanlarının Karşılaştırılması}

Kontrol grubundaki öğrencilerin ön test son test başarı puanları arasındaki fark puanları incelendiğinde normal dağılım göstermediği tespit edilmiştir. Bu sebeple kontrol grubunun ön test son test puanlarının karşılaştırılması parametrik olmayan testlerden Wilcoxon İşaretli Sıralar Testi kullanılarak yapılmıştır. Analiz sonuçları Tablo 2' de verilmiştir.

Tablo 2. Kontrol Grubu Öğrencilerinin Ön Test- Son Test Puanlarının Wilcoxon İşaretli Sıralar Testi ile Karşılaştırılması.

\begin{tabular}{llllll}
\hline Ön Test- Son Test Ölçümü & $N$ & Sıra Ortalaması & Sıra Toplamı & $z$ & $p$ \\
\hline Negatif sıralar & $2^{\text {a }}$ & 14,96 & 374,00 & $-4,493$ &, $000^{*}$ \\
Pozitif Sıralar & $2^{\text {b }}$ & 2 & 4,00 & & \\
Fark Olmayan & $1^{\text {c }}$ & & & & \\
\hline
\end{tabular}

${ }^{*} p<0,05$

a. Son Test Başarı Puanı > Ön Test Puanı 
b. Son Test Başarı Puanı < Ön Test Puanı

c. Son Test Başarı Puanı = Ön Test Puanı

Analiz sonuçlarına göre, kontrol grubunun ön test başarı puanı ve son test başarı puanları arasındaki farkın anlamlı olduğu görülmektedir $[z=-4,49, p<.05]$. Fark puanlarının sıra ortalaması ile toplamı incelendiğinde bu farkın son test puanları lehine olduğu tespit edilmiştir. Bu durum, mevcut öğretim yönteminin 5. sınıf “Ondalık Gösterim” kazanımlarının öğrenilmesinde etkili olduğunu ve başarıyı arttırdığını göstermektedir.

Kontrol grubu öğrencilerinin ön test başarı puan ortalamaları $X=12,17$, son test başarı puan ortalamaları $X=15,79$ olarak belirlenmiştir. Kontrol grubu öğrencilerinin son test başarı puan ortalamaları ön test başarı puan ortalamalarından yüksektir.

\section{Deney Grubu Öğrencilerinin Ön Test ile Son Test Puanlarnın Karşılaştırılması}

Deney grubundaki öğrencilerin ön test ve son test başarı puanları arasındaki fark puanları incelendiğinde normal dağılım gösterdiği belirlenmiştir. Bu sebeple deney grubunun ön test başarı ve son test başarı puanlarının karşılaştırılması parametrik testlerden İlişkili Örneklemler $t$ Testi kullanılarak yapılmıştır. Analiz sonuçları Tablo 3'te gösterilmiştir.

Tablo 3. Deney Grubu Ön Test- Son Test Puanlarının İlişkili Örneklemler t Testi ile Karşılaştırılması.

\begin{tabular}{lllllll}
\hline Ölçüm & $\boldsymbol{N}$ & $\boldsymbol{X}^{-}$ & $\boldsymbol{S}$ & $\boldsymbol{s} \boldsymbol{d}$ & $\boldsymbol{t}$ & $\boldsymbol{p}$ \\
\hline Ön Test & 28 & 11,89 & 3,77 & 27 & $-8,74$ &, $000^{*}$ \\
\hline Son Test & 28 & 17,50 & 2,56 & & & \\
\hline
\end{tabular}

Deney grubunun ön test başarı puan ortalamaları ( $X$ Ön test $=11,89$ ) ile son test başarı puan ortalamaları $\left(X^{-}\right.$Son test $\left.=17,50\right)$ arasındaki farkın anlamlı olduğu belirlenmiştir $[t(27)=-8,74, p<0.01]$. Etki büyüklügü $(d=1,6)$ hesaplanarak farkın çok büyük olduğu tespit edilmiştir. Bu sonuçlar Gerçekçi matematik eğitiminin başarıyı arttırmada anlamlı bir etkisinin olduğunu göstermektedir.

\section{Deney Grubu ile Kontrol Grubu Öğrencilerinin Son Test Başarı Puanlarının Karşılaştırılması}

Deney ve kontrol gruplarının son test başarı puanları iki grup içinde normallik şartı sağlanamadığından ortalamalar parametrik olmayan testlerden Mann Whitney $U$ testi ile karşılaştırılmıştır. Tablo 4 'te analiz sonuçları verilmiştir.

Tablo 4. Deney ve Kontrol Gruplarının Son Test Puanları Mann Whitney U Testi Karşılaştırılması.

\begin{tabular}{llllll}
\hline Grup & $N$ & Sira Ortalaması & Sira Toplamı & $U$ & $p$ \\
\hline Deney & 28 & 33,57 & 940,00 & 250,000 &, $019^{*}$ \\
Kontrol & 28 & 23,43 & 656,00 & & \\
\hline
\end{tabular}

Analiz sonuçları doğrultusunda, deney grubu ile kontrol grubunun son test başarı puanları arasında anlamlı fark vardır $(U=250, p<.05)$.

Bu sonuçlar göz önüne alınarak GME destekli öğretim yönteminin, mevcut öğretim yöntemine göre 5. sınıf "Ondalık Gösterim" konusunun öğretiminde daha başarılı olduğu ifade edilebilir.

Deney grubu son test başarı puan ortalaması $X=17,50$, kontrol grubu son test başarı puan ortalaması $X=15,79$ olarak hesaplanmıştır. Deney grubu son test başarı puan ortalamaları kontrol grubunun son test başarı puan ortalamalarından yüksektir. Bu sonuçlara dayanarak, GME yöntemi başarıyı arttırmada mevcut öğretim yöntemine göre daha etkili olmuştur. 


\section{Deney Grubu ile Kontrol Grubu Öğrencilerinin Kalıcılık Testi Başanı Puanlarının Karşılaştırılması}

Deney ve kontrol gruplarına uygulama bitiminden 8 hafta sonra "Ondalık Gösterim Başarı Testi" kalıcılık testi olarak uygulanmıştır. Grupların kalıcılık testi başarı puanlarının normal dağılım göstermediği tespit edilmiştir. Bu durumda iki grubun kalıcılık testi puanlarının karşılaştırılması parametrik olmayan testlerden Mann Whitney U testi ile incelenmiştir. Analiz sonuçları Tablo 5'te verilmiştir.

Tablo 5. Deney ve Kontrol Gruplarının Kalıcılık Testi Puanları Mann Whitney U Testi Karşılaştırılması.

\begin{tabular}{llllll}
\hline Grup & $\boldsymbol{N}$ & S1ra Ortalamasi & Sira Toplamı & $\boldsymbol{U}$ & $\boldsymbol{p}$ \\
\hline Deney & 28 & 32,45 & 908,50 & \multirow{2}{*}{281,500} & \multirow{2}{*}{$067^{*}$} \\
Kontrol & 28 & 24,55 & 687,50 & & \\
\hline
\end{tabular}

Analiz sonuçları, deney grubu öğrencileri ile kontrol grubu öğrencilerinin kalıcılık testi başarı puanları arasındaki farkın anlamlı olmadığını göstermiştir $(U=281,5 ; p>.05)$.

Kalıcılık testi puan ortalamaları, deney grubu öğrencilerinde $X=17,71$, kontrol grubu öğrencilerinde $X=15,79$ olarak hesaplanmıştır. Deney grubunun ortalaması kontrol grubunun ortalamasından yüksektir. Bu sonuçlar doğrultusunda, GME yönteminin mevcut öğretim yöntemine göre bilgi kalıcılığını arttırmada daha etkili olduğu ifade edilebilir.

\section{Kontrol Grubunun Kalıcılık Testi ve Son Test Puanlarının Karşılaştırılması}

Kontrol grubunun kalıcılık testi - son test puan farklarının normalliği kontrol edilmiştir ve normal dağılıma sahip olmadığı tespit edilmiştir. Bu sebeple, kontrol grubu öğrencilerinin kalıcllık testison test başarı puanları parametrik olmayan testlerden Wilcoxon İşaretli Sıralar Testi kullanılarak karşılaştırılmıştır. Analiz sonuçları Tablo 6’da verilmiştir.

Tablo 6. Kontrol Grubu Öğrencilerinin Kalıcılık Testi- Son Test Puanlarının Wilcoxon İşaretli Sıralar Testi ile Karşılaştırılması.

\begin{tabular}{llllll}
\hline Kalıcılık Testi-Son Test Ölçümü & $N$ & Sıra Ortalaması & Sıra Toplamı & $z$ & $p$ \\
\hline Negatif sıralar & $12^{\text {a }}$ & 9,46 & 113,50 & $-0,071$ &, $943^{*}$ \\
Pozitif Sıralar & $9^{\mathrm{b}}$ & 13,06 & 117,50 & & \\
Fark Olmayan & $7^{\mathrm{c}}$ & & & & \\
\hline
\end{tabular}

${ }^{*} p>0,05$

a. Son Test Başarı Puanı > Kalıcılık Testi Puanı

b. Son Test Başarı Puanı $<$ Kalıcılık Testi Puanı

c. Son Test Başarı Puanı = Kalıcılık Testi Puanı

Tablo 6 incelendiğinde $\mathrm{p}$ değerinin .05 den büyük olduğu görülmektedir. Analiz sonuçları, mevcut öğretim yönteminin uygulandığı kontrol grubunun kalıcılık testi başarı puanları ile son test başarı puanları arasındaki farkın anlamlı olmadığını göstermektedir. Ayrıca kontrol grubu öğrencilerinin son test puan ortalamaları ile kalıcılık testi puan ortalamaları birbirine eşit olup $X=15,785^{\prime}$ dir. Son test puanlarının standart sapma değeri 2,89 iken kalıcılık testi puanlarının standart sapmasi 3,21'dir.

\section{Deney Grubunun Kalıcılık Testi ve Son Test Puanlarının Karşılaştırılması}

Deney grubu öğrencilerinin kalıcılık testi - son test başarı puan farklarının normalliği kontrol edilmiştir ve normal dağılım göstermediği belirlenmiştir. Bu sebeple, deney grubunun kalıcılık testi- 
son test puanları parametrik olmayan testlerden Wilcoxon İşaretli Sıralar Testi kullanılarak karşılaştırılmıştır. Analiz sonuçları Tablo 7'de verilmiştir.

Tablo 7. Deney Grubu Öğrencilerinin Kalıcılık Testi- Son Test Puanlarının Wilcoxon İşaretli Sıralar Testi ile Karşılaştırılması.

\begin{tabular}{lccccc}
\hline Kalıcılık testi-Son Test Ölçümü & $\boldsymbol{N}$ & Sıra Ortalaması & Sıra Toplamı & $\boldsymbol{z}$ & $\boldsymbol{p}$ \\
\hline Negatif sıralar & $12^{\mathrm{a}}$ & 13,67 & 164,00 & $-0,041$ &, $967^{*}$ \\
Pozitif Sıralar & $13^{\mathrm{b}}$ & 12,38 & 161,00 & & \\
Fark Olmayan & $3^{\mathrm{c}}$ & & & & \\
\hline
\end{tabular}

$* p>0,05$

a. Son Test Başarı Puanı > Kalıcılık Testi Puanı

b. Son Test Başarı Puanı < Kalıcılık Testi Puanı

c. Son Test Başarı Puanı = Kalıcılık Testi Puanı

Tablo 7 incelendiğinde p değerinin .05 den büyük olduğu görülmektedir. Analiz sonuçları, GME'nin uygulandığı deney grubunun kalıcılık testi başarı puanları ile son test başarı puanları arasında anlamlı fark olmadığını göstermektedir. İncelenen fark puanlarının sıra ortalaması ve toplamına göre kalıcılık testi puanları lehine bir fark olduğu görülmektedir. Deney grubu öğrencilerinin son test puan ortalamaları $X=17,50$ iken kalıcılık testi puan ortalamaları $X=17,71$ olarak hesaplanmıştır. Deney grubu öğrencilerinin kalıcılık testi başarı puan ortalamaları son test başarı puan ortalamalarından yüksektir.

\section{Öğrenci Görüşlerine İlişkin Bulgular}

28 deney grubu öğrencisine uygulanan görüşme formu ile öğrencilerin GME yaklaşımına ilişkin görüşlerine başvurulmuştur. Görüşme formundan edinilen veriler içerik analizi ile incelenmiştir. Görüşme formuna verilen örnek cevaplar aşağıdaki şekildedir:

Soru 1: Gerçekçi matematik eğitimi ile yapılan öğretimin size katkıları oldu mu? Katkısı olduğunu düşünüyorsanız, ne gibi katkıları olmuştur?

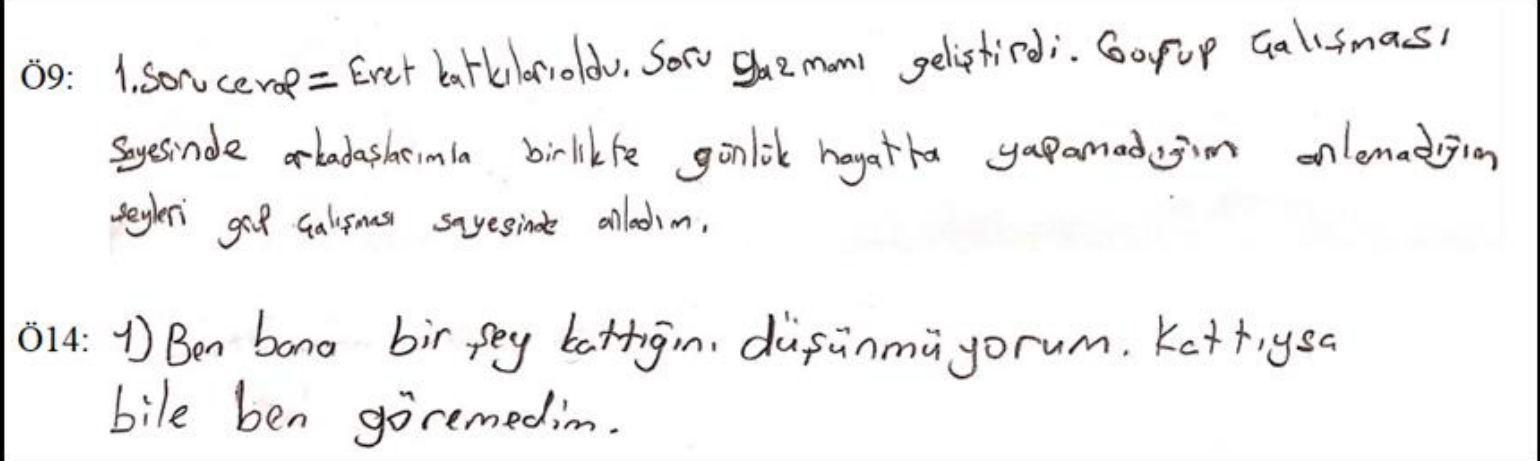

Şekil 1. Görüşme Formu Birinci Soruya Verilen Örnek Öğrenci Cevapları.

Öğrencilerin tamamına yakını GME yaklaşımıyla işlenen dersin daha güzel ve eğlenceli olduğunu söylemişlerdir. Ayrıca arkadaşlarıyla birlikte etkinlik yapmaktan çok hoşlandıklarını belirtmişlerdir. Bir öğrenci ise bu şekilde işlenen dersin kendisine katkısı olmadığını söylemiştir.

Soru 2: Gerçekçi matematik eğitimi ile yapılan öğretim, matematiğe olan ilgi ve tutumunuzu nasıl etkiledi? Olumlu ya da olumsuz bir etki olmuş ise sizdeki ilgi ve tutum değişimini destekleyen örnek verebilir misiniz? 
Ö3: 2) Grup Galismasipdah Keyif alyorum. Normal matematige göre daha istektigim. Herkesin fikri alingor ve daha eglenceli

Ö19: 2 Pek de fazla ettillemed' ama yine de biraz etriledi.

Şekil 2. Görüşme Formu İkinci Soruya Verilen Örnek Öğrenci Cevapları.

Öğrencilerin tamamına yakını GME ile yapılan öğretimin matematik ilgilerini arttırdığını ve tutumlarını olumlu yönde etkilediğini belirtmişlerdir. Bir öğrenci ise ilgi ve tutumunu biraz etkilediğini belirtmiştir.

Soru 3: Gerçekçi matematik eğitimi ile öğretimin yapıldığı matematik derslerinin, bu öğretimin yapılmadı $\breve{1}$ matematik derslerinden farkı nedir?

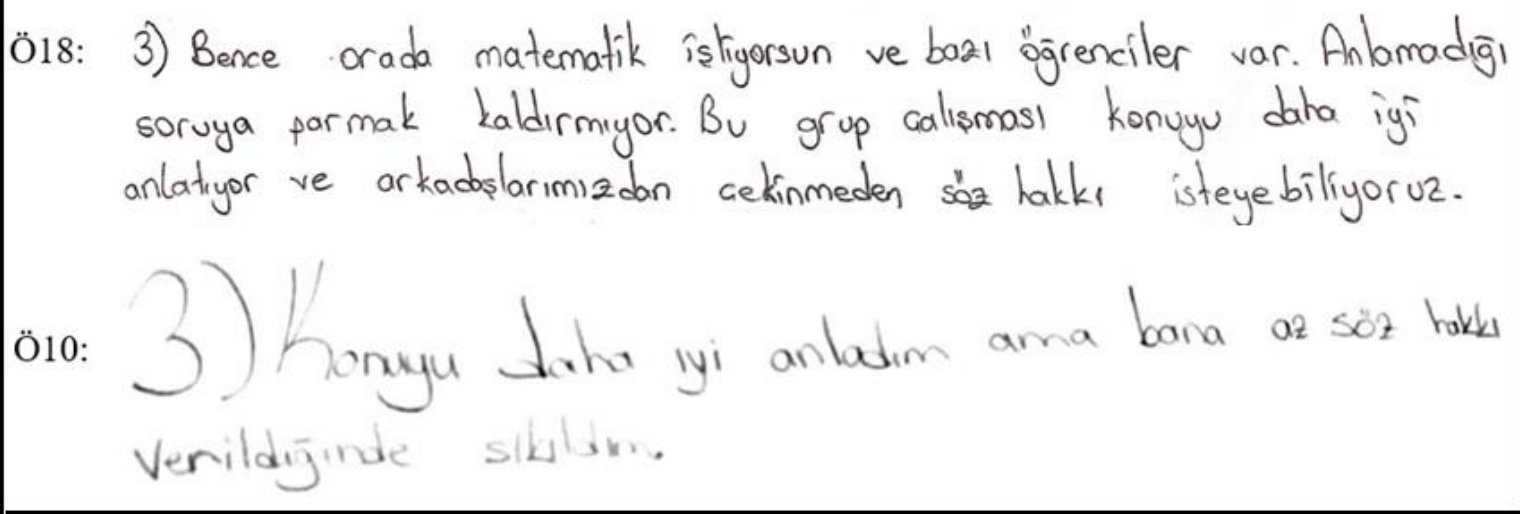

Şekil 3. Görüşme formu üçüncü soruya verilen örnek öğrenci cevapları.

Öğrencilerin tamamına yakını GME ile yapılan öğretimin konuyu daha iyi anlamalarına katkıda bulunduğunu ve daha ilgi çekici olduğunu belirtmişlerdir. Bir öğrenci ise konuyu daha iyi anladığını fakat gruptaki arkadaşlarının kendisine az söz hakkı vermesinden dolayı sıkıldığını söylemiştir.

Soru 4: Gerçekçi matematik eğitimi ile öğretimin, diğer matematik konularında da yapılmasını ister misiniz? Diğer konularda da yapılmasını istiyorsanız kısaca sebebini açıklayınız.

\section{ö15: 4) Everisterim ciunkiu Sorularin farkl cözzunterini ar kados armdan ögrenuis olvrum.}

Ö1: 4) istiyorum. Cunks konuys daha iyi anliyorum ve daha hizli, doğru ciözüyorum. 
Şekil 4. Görüşme Formu Dördüncü Soruya Verilen Örnek Öğrenci Cevapları.

Öğrencilerin tamamı GME ile öğretimin diğer konularda da yapılmasını istemiştir. Bunun sebebini daha öğretici ve eğlenceli olarak açıklamışlardır.

Soru 5: Yapılan çalışma sonucunda günlük hayatta karşılaşılan problemleri daha iyi çözebileceğinizi düşünüyor musunuz? Fayda sağlayacağını düşünüyor iseniz size ne gibi durumlar için fayda sağlayacağını açıklayınız.

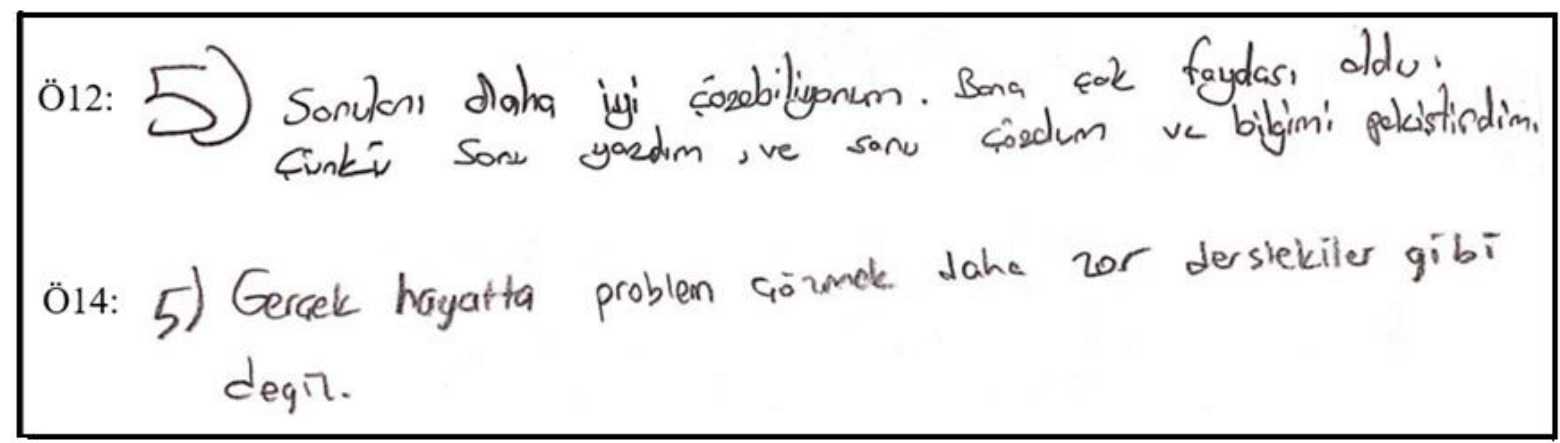

Şekil 5. Görüşme Formu Beşinci Soruya Verilen Örnek Öğrenci Cevapları.

Öğrencilerin tamamına yakını sınıfta yapılan etkinliklerin günlük hayat problemlerini çözmelerine olumlu yönde katkısı olduğunu ifade etmiştir. Derste çözülen problemlerin günlük hayattan örnekler olmasına dikkat çekmişlerdir. Bir öğrenci ise günlük hayatta çözümü daha zor problemler çıktığını söylemiştir.

Soru 6: Gerçekçi matematik eğitimi ile öğretim hakkında düşüncelerini kısaca belirtiniz.

\section{Ö16:

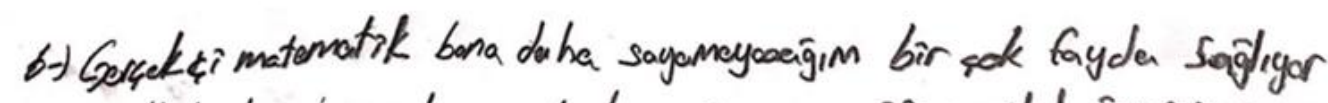

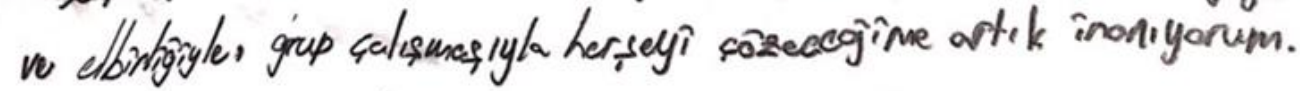
Ö26: 6) Daha eǵlenceli hale geldi. Soru Görmeyi taha aok seudim,

Şekil 6. Görüşme Formu Altıncı Soruya Verilen Örnek Öğrenci Cevapları.

Öğrencilerin tamamı GME ile yapılan öğretimin daha eğlenceli ve faydalı olduğunu belirtmişlerdir. Konuyu daha iyi öğrendiklerini ve yardımlaşarak daha iyi anladıklarını ifade etmişlerdir.

\section{Tartışma, Sonuç ve Öneriler}

Bu araştırmada ortaokul 5. sınıf ondalık gösterimler konusunda GME yaklaşımın uygulandı̆̆ı deney grubu öğrencileri ile mevcut öğretim yönteminin uygulandığı kontrol grubu öğrencilerinin akademik başarı düzeyleri arasında istatistiksel olarak anlamlı farklılıkların olup olmadığı incelenmiştir.

Araştırmanın başlangıcında deney ve kontrol grubu öğrencilerine araştırmacı tarafından hazırlanan Ondalık Gösterim Başarı Testi ön test olarak uygulanmıştır. Grupların ön test puanları 
incelendiğinde istatistiksel olarak anlamlı bir farklılık bulunamamıştır. Diğer bir ifade ile araştırma başlangıcında deney ve kontrol grubunda yer alan öğrencilerin ondalık gösterimler konusundaki akademik başarı düzeyleri birbirine eşdeğer düzeydedir. Bu durum GME'nin etkililiğinin daha iyi anlaşılması açısından önemlidir.

Dört hafta süren uygulama sonucunda her iki gruba son test olarak uygulanan Ondalık Gösterim Başarı Testi sonuçları istatistiksel olarak karşılaştırmalı incelendiğinde deney ve kontrol grubu öğrencilerinin son test başarı düzeylerinin ön test puanlarına göre anlamlı düzeyde arttı̆̆ belirlenmiştir.

Deney grubu öğrencilerinin matematik başarılarını artırmada gerçek durum problemleri ile öğrenmeye başladıkları ve soyut matematiksel bilginin yatay ve dikey matematikselleştirme ile somutlaştırılarak anlamlandırmalarını sağladığı söylenebilir. Başka bir deyişle, GME yaklaşımı öğrencilerin akademik başarılarını iyileştirmek üzerinde olumlu bir etkiye sahip olduğu söylenebilir.

Araştırmada ulaşılan sonuçlar literatürde yapılan araştırma sonuçları ile örtüşmektedir. Aydın Ünal (2008), Demirdöğen (2007), Hirza, vd. (2014), Keijzer'in (2003), Korkmaz (2017), Marija, Lidija, ve Simona (2000), Nama Aydın (2014), Özdemir (2015), Özkaya (2016), Uygur (2012), Yuberta vd. (2011) tarafından gerçekleştirilen çalışmalarda da GME'nin öğrenci başarısını artırdığı belirlenmiştir. Uygulama bitiminde gruplara uygulanan son testin puanları karşılaştırılarak incelendiğinde, deney grubu öğrencilerinin son test puanları, kontrol grubu öğrencilerinin son test puanlarından istatistiksel olarak anlamlı düzeyde yüksek çıkmıştır. Bu sonuçlar gerçekçi matematik eğitiminin, mevcut öğretim yöntemine göre 5. sınıf "Ondalık Gösterim" konusu kazanımlarının edinilmesinde daha etkili ve başarılı olduğunu göstermektedir. Ulaşılan bu sonuç, literatürde GME'nin etkinliğini incelemeye yönelik diğer araştırma bulguları ile örtüşmektedir.

Uygulama bitiminden 8 hafta sonra her iki gruba kalıcllı testi olarak uygulanan Ondalık Gösterim Başarı Testi puanları karşılaştırılarak incelendiğinde gruplar arasında istatistiksel olarak anlamlı fark olmadığı tespit edilmiştir. Deney grubu öğrencilerinin kontrol grubundaki öğrencilere göre başarı ortalamalarının biraz daha yüksek olduğu belirlenmiştir. Bu sonuçlar gerçekçi matematik eğitiminin, mevcut öğretim yöntemine göre 5. sınıf "Ondalık Gösterim" konusu kazanımlarının kalıcılığının sağlamasında daha etkili ve başarılı olduğunu göstermektedir. Konu ile ilgili literatürde yapılan araştırmalar incelendiğinde de araştırma bulgumuzu destekleyen sonuçlara ulaşıldığı görülmektedir. Aydın-Ünal \& İpek (2009), Büyükikiz Kütküt (2017), Çilingir Altıner \&Artut (2017), Hirza vd. (2014), Keijzer'in (2003), Taş (2018) tarafından gerçekleştirilen çalışmalarda da GME'nin öğrenci başarısını artırmada etkili olduğu tespit edilmiştir.

Deney grubu ve kontrol grubu öğrencilerinin son test başarı puanları ile kalıcılık testi başarı puanları arasında istatistiksel olarak anlamlı fark bulunamamıştır. Kontrol grubu öğrencilerinin son test ile kalıcılık testi puan ortalamaları birbirine eşit bulunmuştur. Deney grubu öğrencilerinin ise kalıcılık testi başarı ortalamasının, son test puanlarından daha yüksek olduğu tespit edilmiştir. Bu sonuç, GME'nin 5. sınıf “Ondalık Gösterim” konusu kazanımlarının kalıcılığının sağlamasında etkinliğini göstermektedir. Bu sonuçlar doğrultusunda, GME 5.sınıf Ondalık Gösterim konusunda öğrenci başarısını mevcut öğretim yöntemine göre anlamlı düzeyde artırmakta, kalıcılığa ise anlamlı düzeyde etki etmemektedir. GME öğrencilerin matematik öğretim programında yer alan kavramsal ve işlemsel durumlarla günlük hayatlarında karşılaştıkları durumların ilişkilendirildiği etkinliklerde aktif rol almaları öğrencilerin akademik başarılarının artırılmasında etkili olduğu savunulabilir.

Literatürde yapılan araştırmalara bakıldığında Demir (2017) katı cisimlerin yüzey alanları ve hacim öğretiminde, Erdoğan (2018) cebir öğrenme alanında, Marija vd. (2000) aritmetik öğretiminde, Nama Aydın (2014) kesirlerin öğretiminde, araştırmalarında GME ile işlenen derslerin kalıcılığa 
etkisinin olduğunu saptarken, Taş (2018) hacim ölçme ve sıvıları ölçme birimleri öğretiminde GME ile işlenen derslerin kalıcılığa etkisinin olmadığını saptamıştır. Araştırma bulgularının örtüşmeme nedeninin GME'nin işlenen her konu üzerinde aynı etkiyi yapmayacağını düşündürmektedir. Araştırmanın, ortaokula adaptasyon sürecinde olan 5.sınıflar üzerinde yapılması ve sınıf mevcutlarının fazla olması öğrencilerin grup çalışmasına alışmalarında geçen süreyi nispeten olumsuz etkilemiştir. Daha üst kademelerden öğrencilerle çalışmak, grup çalışmasına alışma süresini kısaltabilir. Böylelikle zamanın çoğu etkinliklere ayrılabilir.

Öğretim programında "Ondalık Gösterim" konusuna ayrılan sürenin azlığı, 5.sınıf öğrencilerinin bu konuyu ilk kez öğreniyor olmaları uygulamayı yavaşlatmıştır ve zorlaştırmıştır. Özellikle deney grubunda yapılan çalışmalarda sınıfın fiziki koşulları, akıllı tahta olmaması, materyal sınırlılığı işlenişi zorlaştırmıştır. Mevcudun daha az ve fiziksel koşulların daha elverişli olduğu siniflarda uygulamadan daha fazla verim alınabilir.

Öğretmen eğitimi programlarında GME yaklaşımı ve buna ilişkin uygulamalı çalışmalar yer alabilir. Öğretmen adaylarının hizmet öncesinde GME yaklaşımıyla karşılaşmaları bu öğretim yaklaşımını uygulamaya geçirmelerini kolaylaştırabilir.

Öğretmenlerin, öğretim materyalleri ve kaynak çeşitliliği açısından desteklenmesi ile GME yaklaşımı etkili bir biçimde uygulanabilir. Öğrencilerin bir bilim insanı gibi matematiği yeniden keşfetmelerine imkân verecek nitelikte materyallere ulaşmalarına olanak tanınmalıdır.

\section{Araştırma ve Yayın Etiği Beyanı}

T.C. Hasan Kalyoncu Üniversitesi Sosyal ve Beşerî Bilimler Etik Kurulu 02.07.2020 tarihli 804.01E.2007020011 Sayılı kararıyla rapor alınmıştır.

\section{Yazarların Makaleye Katkı Oranları}

Araştırmada, yazarların katkıları aynı oranda üstlenilmiştir.

\section{Çıkar Beyanı}

Bu çalışmada yazarlar arasında çıkar çatışması bulunmamaktadır.

\section{Kaynakça}

Akay, C. \& Ültanır, E. (2010). Andragojik temellere dayalı kolaylaştırılmış okuma-yazma eğitimi (KOYE) sürecine yönelik KOYE eğiticilerinin görüşleri. Mersin Üniversitesi Ĕ̆itim Fakültesi Dergisi, (6), 75-88.

Akkaya, R. (2010). Olasıllk ve istatistik öğrenme alanındaki kavramların gerçekçi matematik eğitimi ve yapılandırmacılık kuramına göre bilgi oluşturma sürecinin incelenmesi. (Yayınlanmamış Doktora Tezi). Uludağ Üniversitesi, Bursa.

Altun, M. (2004). Matematik öğretimi (6, 7 ve 8. sinıflarda). Erkan.

Altun, M. (2006). Matematik öğretiminde gelişmeler. Uludă̆ Üniversitesi Ĕ̆itim Fakültesi Dergisi, XIX (2), 223-238.

Aydın Ünal, Z. (2008). Gerçekçi matematik eğitiminin ilköğretim 7. sınıf öğrencilerinin başarılarına ve matematiğge karşı tutumlarına etkisi. (Yayınlanmamış Yüksek Lisans Tezi). Atatürk Üniversitesi Fen Bilimleri Enstitüsü, Erzurum.

Aydın Ünal, Z. \& İpek, A. S. (2009). Gerçekçi matematik eğitiminin ilköğretim 7.sınıf öğrencilerinin tam sayılarla çarpma konusundaki başarılarına etkisi. Ĕ̆itim ve Bilim, 34(152), 60-70.

Aykaç, S. (2008). Illköğretim 6.sını öğrencilerinin ondalık sayıların öğreniminde karşılaştıkları gü̈clükler ve çözüm önerileri. (Yayınlanmamış Yüksek Lisans Tezi). Atatürk Üniversitesi Fen Bilimleri Enstitüsü, Erzurum. 
Barnes, H. (2004). Realistic mathematics education: Eliciting alternative mathematical conceptions of learners. African Journal of Research in SMT Education, (8), 53-64

Bıldırcın, V. (2012). Gerçekçi matematik eğitimi (GME) yaklaşımının ilköğretim beşinci sınıflarda uzunluk, alan ve hacim kavramlarının öğretimine etkisi. (Yayınlanmamış Yüksek Lisans Tezi). Ahi Evran Üniversitesi Sosyal Bilimler Enstitüsü, Kırşehir.

Büyükikiz Kütküt, H. (2017). Gerçekçi matematik eğitimi yaklaşımının ortaokul matematik derslerinde kullanımının incelenmesi ve öğrenci başarısına etkisi. (Yayınlanmamış Yüksek Lisans Tezi). Çukurova Üniversitesi Sosyal Bilimler Enstitüsü, Adana.

Creswell, J. W. (2013). Research design: Qualitative, quantitative, and mixed methods approaches (2nd ed.). Sage.

Creswell, J. W. (2016). Araştırma deseni: Nitel, nicel ve karma yöntem yaklaşımları (2. bs.). (S. B.Demir, Çev.). Eğiten Kitabevi.

Creswell, J. W. (2017). Karma Yöntem Araştırmalarına Giriş. (M. Sözbilir, Çev.). Pegem Akademi.

Çilingir Altıner, E. \& Artut, C. (2017). İlkokulda gerçekçi matematik eğitimi ile gerçekleştirilen öğretimin öğrencilerin başarısına, görsel matematik okuryazarllğına ve problem çözme tutumlarına etkisi. Marmara Üniversitesi Atatürk Eğitim Fakültesi Ĕ̆itim Bilimleri Dergisi, (12), 119.

Demir, G. (2017). Gerçekçi matematik eğitimi yaklaşımının meslek lisesi öğrencilerinin matematik kaygısına, matematik özyeterlik algısına ve başarısına etkisi. (Yayınlanmamış Yüksek Lisans Tezi). Adnan Menderes Üniversitesi Sosyal Bilimler Enstitüsü, Aydın.

Demirdöğen, N. (2007). Gerçekçi matematik öğretimi yönteminin ilköğretim 6.sınıflarda kesir kavramının öğretimine etkisi. (Yayınlanmamış Yüksek Lisans Tezi). Gazi Üniversitesi Eğitim Bilimleri Enstitüsü, Ankara.

Dursun, Ş. ve Dede, Y. (2004). Öğrencilerin Matematikte Başarısını Etkileyen Faktörler: Matematik Öğretmenlerinin Görüşleri Bakımından. Gazi Eğitim Fakültesi Dergisi, 24(2), 217-230.

Erden, M. \& Akman, Y. (2002). Gelişim ve öğrenme. (11. Baskı). Arkadaş.

Erdoğan, H. (2018). Gerçekçi matematik eğitimine dayalı matematik öğretiminin akademik başarı, kalıcılık ve yansıtıcı düşünme becerisine etkisi. (Yayınlanmamış Yüksek Lisans Tezi). Pamukkale Üniversitesi Eğitim Bilimleri Enstitüsü, Denizli.

Fauzan, A. (2002). Applying realistic mathematics education in teaching geometry in Indonesian primary schools. Doctoral dissertation, University of Twente, Enschede.

Hırza, B., Kusumah, Y. S., Darhim, D. \& Zulkardi, Z. (2014). Improving intution skills with realistic mathematics education. IndoMS-JME, 5(1), 27-34.

Ismunandar, D., Gunadi, F., Taufan, M., Mulyana, D. \& Runisah (2020). Creative thinking skill of students through realistic mathematics education approach. Journal of Physics: Conference Series

Karasar, N. (2018). Araştırmalarda Rapor Hazırlama (20. bs.). Nobel Akademi.

Keijzer, R. (2003). Teaching formal mathematics in primary education. Utrecht: CDBeta.

Korkmaz, E. (2017). Dönüşüm geometrisi konularının gerçekçi matematik eğitimi (GME) etkinlikleriyle işlenmesinin öğrenci başarısına ve matematik tutumuna etkisi. (Yayınlanmamış Doktora Tezi). İnönü Üniversitesi Eğitim Bilimleri Enstitüsü, Malatya.

Marija, K., Lidija, M. \& Simona, T. (2000). Development of intervention program in mathematics in regular classes for children with low early mathematical competence. International Special Education Congress. University of Manchester, Manchester.

Nama Aydın, G. (2014). Gerçekçi matematik eğitiminin ilkokul 3. sını öğrencilerine kesirlerin öğretiminde başarıya kahıcilı̆̆a ve tutuma etkisi. (Yayınlanmamış Yüksek Lisans Tezi). Abant İzzet Baysal Üniversitesi Eğitim Bilimler Enstitüsü, Bolu.

Olkun, S. \& Toluk Uçar, Z. (2003). Ilköğretimde etkinlik temelli matematik öğretimi. Anı.

Özdemir, H. (2015). Gerçekçi matematik eğitimi yaklaşımının ortaöğretim 9. sımı kümeler ünitesi öğretiminde öğrenci başarısına etkisi. (Yayınlanmamış Yüksek Lisans Tezi). Atatürk Üniversitesi Eğitim Bilimleri Enstitüsü, Erzurum. 
Özkaya, A. (2016). 5. sımıf matematik dersinde gerçekçi matematik eğitimi destekli öğretimin öğrenci başarısına, tutumuna ve matematik öz bildirimine etkisi. (Yayınlanmamış Doktora Tezi). Gazi Üniversitesi Eğitim Bilimleri Enstitüsü, Ankara.

Palabıyık, E. (2016). İlköğretim 4. ve 5. sinıf öğrencilerinin ondalık sayılar konusunda hata ve kavram yanılgılarının tespiti ve analizi. (Yayınlanmamış Yüksek Lisans Tezi). Ege Üniversitesi Sosyal Bilimler Enstitüsü, İzmir.

Şahin, F. (2004). Orta öğretim öğrencilerinin ve üniversite öğrencilerinin matematik korku düzeyleri. Eğitim Bilimleri ve Uygulama Dergisi, 3(5),57-74.

Taş, T. E. (2018). Gerçekçi matematik eğitimi destekli öğretim yönteminin ilköğretim 6. sinıf öğrencilerinin matematik başarılarına ve tutumlarına etkisi. (Yayınlanmamış Yüksek Lisans Tezi). Çukurova Üniversitesi Sosyal Bilimler Enstitüsü, Adana.

TDK (Türk Dil Kurumu) (2020). Genel Açıklamalı Sözlük. TDK Yayınları.

Uygur, S. (2012). 6. sınıf kesirlerle çarpma ve bölme işlemlerinin öğretiminde gerçekçi matematik eğitiminin öğrenci başarısına etkisi. (Yayınlanmamış Yüksek Lisans Tezi). Atatürk Üniversitesi Eğitim Bilimleri Enstitüsü, Erzurum.

Van der Kooij, H. (2001). Algebra: a tool for solving problems. In (F. L. Lin, Dü.) Common sense in mathematics education, (pp. 135-152), Proceedings of 2001 The Netherlands and Taiwan Conference on Mathematics Education, Taipei, Taiwan.

Van De Walle, J. A., Karp, K. S., \& Bay-Williams, J. M. (2014). İlkokul ve ortaokul matematiği: gelişimsel yaklaşımla öğretim. Nobel.

Yuberta, K. R., Zulkardı, Z., Hartono, Y. \& Galen F. V. (2011). Developing student's notion of measurement unit for area. IndoMS. J.M.E, 2(2), 173- 184.

\section{EXTENDED SUMMARY}

There are some theories that have an effect on mathematics in making the mathematics lesson more concrete. At the beginning of these theories, the theory of Realistic Mathematics Education (RME), whose theoretical development dates back to ancient times, and which, like the constructivist approach, can be called up-to-date both theoretically and practically, draws attention (Altun, 2006).

As with many subjects in mathematics, students have difficulties in decimal notation that is explained in fractions and they fall into misconceptions. Saying that 0.75 is the same as $3 / 4$ can be confusing for children. The main purpose of teaching fraction and decimal notation is to make it clear that these numbers express the same concept (Aykaç, 2008). In daily life, decimal representations are often encountered rather than fractions, and decimal notations are used instead of fractions when operating in calculators. The knowledge, skills and practices related to decimal notations will be reflected in subsequent learning and practice in daily life. Incomplete and wrong information about the subject will gain continuity and reflect on the whole lives of individuals (Palabiyik, 2016). In this sense, it is thought that this research will contribute to the mathematics education literature. The aim of this research is to examine the effect of realistic mathematics education approach on academic achievement in secondary school 5 th grade decimal notations.

Mixed method was used in the research. The quasi-experimental design model with pre-test post-test control group was used in the quantitative dimension of the study, while the interview technique was used in the qualitative dimension. The study was conducted on 56 students at the 5th grade level of a state secondary school in Gaziantep. The study group consists of the control group $(n=28)$ and the experimental group $(n=28)$. The data collection tools the academic achievement test and the interview form used in the research were prepared by the researcher. The Unrelated Samples T Test and Mann Whitney U Test were used to compare the scores of the experimental and control groups 
from the achievement tests, and the Wilcoxon Signed Ranks Test was used to compare the results of the achievement tests applied to the groups before, after and at the end of the study.

The results of the analysis show that there is no significant difference between the pre-test achievement mean scores of the students in the experimental and control groups [ $t(54)=0.291, p>.05]$. According to this result, it can be said that at the beginning of the application, the success levels of the students in the experimental and control groups are equivalent to each other in decimal numbers. According to the results of the analysis, it is seen that the difference between the pre-test success score and the post-test success score of the control group is significant [ $z=-4.49, \mathrm{p}<.05]$. It was determined that this difference was in favor of post-test scores. It was determined that the difference between the pre-test achievement mean score of the experimental group ( $X$ Pre-test $=11.89)$ and the post-test achievement mean score $(X$ Posttest $=17.50)$ was significant $[t(27)=-8.74, p<0.01]$. It was determined that this difference was in favor of post-test scores. According to the analysis results, there is a significant difference between the post-test achievement scores of the experimental group and the control group $(\mathrm{U}=250, \mathrm{p}<.05)$. It was determined that this difference was in favor of the experimental group. According to these results, it can be stated that the RME supported teaching method is more successful in teaching the 5th grade "Decimal Notation" subject compared to the current teaching method. The results of the analysis showed that the difference between the retention test achievement scores of the students in the experimental group and the students in the control group was not significant (U=281.5; $p>$.05). Permanence test mean scores were calculated as $X=17.71$ for the experimental group students and as $X=15.79$ for the control group students. According to the results of the analysis, it was determined that the difference between the retention test success scores of the control group to which the current teaching method was applied and the posttest success scores was not significant. Similarly, it was determined that there was no significant difference between the permanence test success scores and the post-test success scores of the experimental group in which RME was applied. With the interview form applied to 28 experimental group students, the students' views on the RME approach were consulted. The data obtained from the interview form were analyzed by content analysis.

At the beginning of the research, the Decimal Notation Achievement Test, prepared by the researcher, was applied to the experimental and control group students as a pre-test. When the pre-test scores of the groups were examined, no statistically significant difference was found. When the results of the Decimal Notation Achievement Test, which was applied to both groups as a post-test as a result of the 4-week application, it was determined that the post-test achievement levels of the students in the experimental and control groups increased significantly compared to the pre-test scores. When the posttest scores applied to the groups at the end of the application were compared and examined, the posttest scores of the experimental group students were statistically significantly higher than the control group students' post-test scores. When the Decimal Notation Achievement Test scores applied to both groups as a retention test were compared 8 weeks after the end of the application, it was determined that there was no statistically significant difference between the groups. There was no statistically significant difference between the post-test achievement scores of the experimental group and the control group students and the permanence test success scores. On the other hand, it was determined that the students in the experimental group had higher permanence test success average than the posttest scores. This result shows the effectiveness of RME in ensuring the permanence of the 5th grade "Decimal Notation" subject gains. According to the results of the research, RME 5th grade decimal notation significantly increases student success compared to the current teaching method, but does not significantly affect permanence. The fact that the research was carried out on 5th grade students who are in the process of adaptation to secondary school and the number of classrooms is large negatively affected the time it took for students to get used to group work. Working with students from higher levels can shorten the time to get used to group work. In this way, most of the time can be devoted to activities. 